\title{
Consumers' reasons for purchasing low involvement goods by mail catalogue: preliminary measurement guidelines
}

\author{
N.S. Terblanché \\ Department of Business Management, University of Stellenbosch, Private Bag X1. Matieland. 7602 South Africa \\ C. Boshoff \\ Department of Business Management, University of Port Elizabeth, Port Elizabeth. South Africa \\ E. vd M. Smit \\ Graduate School of Business, University of Stellenbosch, P.O. Box 610, Bellville 7535, South Africa
}

Received June 1999

\begin{abstract}
New forms and applications of technology have enabled business organisations to increasingly utilise multiple channels for the distribution of retail products. One example, mail-order catalogue buying. has now become an acceptable shopping format for larger numbers of consumers. Earlier research clearly indicated that non-shop shopping. such as buying by mailorder catalogue. is not only very different from shop shopping, but consumers also undertake non-shop shopping for distinct reasons. The primary objective of the research reported here was to identify the reasons underlying the purchasing of low involvement products by mail-order catalogue and to develop a reliable and valid instrument that could identify and measure such reasons.
\end{abstract}

\section{Introduction}

Retailers overcome a number of discrepancies for consumers. Typical discrepancies that are overcome by retailers are time, spatial, assortment and information gaps. Recent years have witnessed a large increase in the volume of retailing transactions done by shopping formats other than conventional retail shops that overcome these discrepancies for consumers. Rosenberg \& Hirschman (1980) stated that, traditionally, shops served as the primary distributors of retail products for three reasons. Firstly, consumers were accustomed to purchase there and secondly because few acceptable alternatives existed. The third reason was that the value of consumers' money exceeded the value of their time. The increased use of multiple channels for the distribution of retail products is a more recent marketing phenomenon. It is especially new forms and applications of technology that makes mail catalogue buying an acceptable shopping format for an increasing number of consumers (McNair \& May, 1978). Earlier research suggested that non-shop shopping is not only very different from in-shop shopping, but consumers also undertake non-shop shopping for distinct reasons. This article specifically deals with the reasons why consumers, who have purchased low involvement products on a number of occasions, buy by mail order.

\section{Objectives}

The primary objective of the research reported here was to identify the reasons underlying the purchasing of low involvement products by mail catalogue. The study assesses empirically whether the eleven generic reasons why consumers buy products by mail-order catalogue, summarised in a later paragraph, are applicable to low involvement goods. The identification of such reasons is of importance for the development of promotions, mail-order catalogue design and product offerings. A further objective was to develop a reliable and valid instrument that could identify and measure the reasons why consumers buy by mail catalogue. Once these reasons have been identified it will be possible (in further studies) to identify factors that influence those reasons for buying or to identify specific market segments to whom certain reasons are particularly relevant.

\section{Theoretical considerations}

In a study of this nature, it is important to take cognisance of the marketplace in which direct order catalogue marketing takes place, together with the reasons why consumers buy via mail order.

\section{Marketplace}

Rapp \& Collins (1990) identified the following trends in and characteristics of the marketplace that favour direct order retailing: target markets (because of changing demographics and lifestyles) change continually; demands on the personal time of consumers; overcrowding by too many new products, services and stores; weakening of the impact of television advertising; decline in brand and store loyalty; and clutter, overkill and waste of advertising. Shopping in retail outlets will undoubtedly remain a vital social as well as a functional activity for a long time to come. There are, however, certain social and economic forces that make shopping in the home attractive. Some of these social and economic forces are: the annoyance and wastefulness of having to battle traffic and shopping crowds; the widely noted deterioration in the quality of service in many retail shops; an increase in the number of career and professional women; a greater emphasis on standardisation and branding of products (which reduces the risk involved in in-home shopping); and the growing use of credit cards (Rapp \& Collins. 1990; Darian, 1987). Rosenberg \& Hirschman (1980) also add the willingness of consumers to change and their acceptance of technology used 
to market products directly, as further reasons that will make shopping in the home increasingly attractive.

\section{Reasons why consumers buy by mail catalogue}

There are many reasons why consumers buy by mail catalogue, many of them based more on perception than on reality, yet very real to the mail catalogue buyer. Hodgson (1980) lists the following as the more frequent factors: convenience, exclusiveness of products offered, fun, economical, 'personal' contact, more information for decision making, lack of embarrassment, simple credit arrangements, wide selection and guaranteed protection. Tucker, as quoted by Macdonald (1993a) concurs with Hodgson in respect of convenience, more information for decision making, wide selection (variety) and guarantees. Various studies related to direct order retailing have identified convenience as the major reason for purchasing by direct order retailing. Gillett (1974) and Cox \& Rich (1967), for instance, found that the major attraction of telephone shopping was its convenience, whilst catalogue shoppers regarded merchandise availability, quality and assortment as the primary motive for shopping by catalogue. According to Darian (1987), in-home shopping potentially offers five different types of convenience, namely:

- reduction of the total amount of time spent on shopping;

- flexibility in the timing of shopping;

- saving of the physical effort of visiting a store;

- saving of aggravation, for example, for mothers of preschool children; and

- opportunity to buy on impulse in response to an advertisement received at home.

Berkowitz, Walton \& Walker (1979) found that, in comparison with supermarket shoppers, shoppers that use an in-home grocery service, attach greater importance to shopping convenience and they have more negative attitudes towards shopping activities than supermarket shoppers. Reynolds (1974) tested three hypotheses to determine whether there is a positive relationship between catalogue buying and convenience. The findings supported the need for convenience in families with children under the age of twelve years. Korgaonkar (1984) also found that nonstore retailing methods will be particularly appealing to convenience-oriented customers. Berry (1979) and McNair \& May (1978) also suggest that nonstore retailers represent an effective means of reducing the time costs associated with information search or shopping and, in doing so, increase convenience for the consumer.

Various authors have identified the wide variety or diversity of merchandise as a reason why consumers buy by mail catalogue (Gillett, 1976; Rosenberg \& Hirschman, 1980; McDonald, 1993a; Reynolds, 1974). Good value, lower price and 'less expensive' are some of the terms used to describe the reason why products are bought by catalogue (McDonald, 1993; Reynolds, 1974; Korgaonkar, 1984; Darian, 1987).

One of the more common reasons why consumers buy via mail catalogue, is because the products that are offered are regarded as unique or exclusive to mail catalogue. McDonald (1993a) found merchandise uniqueness to be one of the eight most important reasons why women's apparel are bought by means of a catalogue. Reynolds (1974) observed and concluded that the strength of catalogues in the future will largely depend on their offspring of unique or distinctive products.
Lumpkin \& Hawes (1985) and McDonald (1993a) also found that the opportunity to evaluate an offer in a catalogue carefully in an unpressurised environment, is a salient attribute of the catalogue-shopping experience. Guarantees, especially money-back guarantees, are not only risk relievers but also serve as incentives to purchase by mail catalogue (Akaah \& Korgoankar, 1988; Hawes \& Lumpkin, 1986).

Gehrt \& Carter (1992) find fun (recreational orientation), to be a reason why consumers buy by mail catalogue. Lumpkin \& Hawes (1985) found that the use of credit was also associated with the frequency of catalogue shopping. Berkowitz. Walton \& Walker (1979) and Cunningham \& Cunningham (1973) established that in-home shoppers have a more liberal attitude toward credit. Lack of embarrassment speaks for itself. Direct mail catalogue offers are very suitable for consumers who do not want to expose their ignorance in respect of a product to a salesperson or who want to purchase personal products in privacy. Based on the preceding literature review the following reasons are investigated in this study:

- The saving of time

- Flexible shopping hours

- Saving of costs

- Exclusiveness of products

- Fun

- 'Personal' contact

- Adequate information for decision making

- Easy credit arrangements

- Wide selection of products offered

- Guarantees offered

- Lack of embarrassment

The saving of time and flexible shopping hours are used as indicators of convenience. It can be expected that the more a consumer perceives any of the above-mentioned reasons to exist, the more the consumer will tend to buy by mail order.

\section{Sample and data collection}

The population of the study was 57823 customers of a South African mail-order organisation who had bought more than twice from the organization in the 18 months preceding the study. A sample of 2500 respondents were drawn from the population. The figure of 2500 respondents was based on an expected response rate of $20 \%$. A response rate of $20 \%$ would have resulted in the return of 500 questionnaires. This was based on a preferred ratio of 15 respondents per item as a norm which would have required 495 completed questionnaires to be returned to meet the desired cutoff point. It must. however, be pointed out that a 5 to 1 ratio is regarded as the minimum whilst a ratio of 10 to 1 is the more acceptable (Hair, Anderson, Tatham \& Black, 1998: 98-99). The questionnaires were mailed to the respondents and a total of 422 questionnaires were returned, giving a response rate of $16.88 \%$. Because of the relatively low response rate, it was necessary to estimate for nonresponse bias. Because the data were captured in the same sequence in which the questionnaires were received, it was possible to use the method called time trends extrapolation as suggested by Armstrong \& Overton (1977), to estimate for nonresponse bias. The assumption underlying this method is that the fourth quartile is the same as the non-respondents. It was therefore necessary to determine whether the demographic characteristics of the 
fourth quartile differs from that of the first quartile. If no differences are found, quartiles one and four as well as the nonresponse are regarded as similar. The demographic characteristics of the first and fourth quartile were analysed to test for significant differences. A Chi-square goodness of fit test did not reveal any significant differences between the demographic variables of the first and the fourth quartiles. Table 1 contains the comparison of the first and fourth quartiles.

Table 1 shows that when the first and fourth quartiles of the realised sample are compared in terms of demographic terms, the two groups do not differ from each other in any respect. As Armstrong \& Overton (1977) argue that non-respondents are similar to the respondents of the fourth quartile, it can therefore be concluded that non-response in this study has minimal impact on the representativeness of the sample.

The mail catalogue organisation does not specialise in any particular merchandise, but offers a wide variety of products in 22 product categories, all of which may be characterised as low involvement products. The low involvement products referred to here have the usual characteristics of low price, little social concern and requiring very limited buying decision making. Typical products offered in the catalogue are cordless headphone sets for television, bathroom scales, sonic pest repellents and a range of apparatus for exercising at home.

\section{Measuring instrument}

A self-administered questionnaire was used as measuring instrument. Thirty three items (33) were generated from the literature to represent the eleven (11) reasons why respondents purchased via mail-order catalogue. Each of the eleven reasons were thus measured by three items. The items that were used, were subjected to an experience survey as suggested by Churchill (1995: 152-153). Two professors of consumer behaviour and five other individuals were asked for their opinions in respect of the suitability of the items to measure the reasons studied. The individuals regarded the items as suitable to measure the reasons studied and the measuring instrument can therefore be deemed to have face validity (Tull \& Hawkins, 1993: 317). Each of the items had to be evaluated on a six-point Likert-type scale ranging from 'agree completely' to 'disagree completely'.

\section{Scale purification}

The scale purification process consisted of three distinct phases: an assessment of the underlying dimensionality (and thus also discriminant validity) using exploratory factor analysis, an assessment of reliability by calculating Cronbach alpha coefficients, and finally, a confirmatory factor analysis.

\section{Dimensionality}

The first step was to assess whether the data do indeed contain eleven dimensions as suggested by the literature study. For this purpose, a Maximum Likelihood Exploratory Factor Analysis was conducted specifying a Direct Quartimum oblique rotation of the original factor matrix (Jenrich \& Sampson, 1966).

As several of the original 33 items did not load a significant extent $(0.40)$ in several solutions or did not demonstrate sufficient discriminant validity by loading on more than one factor, they were deleted as suggested by Churchill (1995). Several factor solutions had been considered and the most interpretable one to emerge was the eight-factor solution shown in Table 2. The factor analysis results suggest that the proposed instrument demonstrates a considerable degree of discriminant validity.

According to Table 2,21 of the original 33 items loaded to a significant extent on one of eight clearly identifiable factors. These factors were defined as:

1. Time saving - time saved because consumers do not have to travel to shops, wait in queues or search for parking (four items). All three of the original items used to measure time saving loaded significantly on this factor as well as one of the items used to measure cost saving. The nonincurring of travel costs were thus interpreted by the respondents as an additional measure of time saving.

Table 1 Comparison of first and fourth quartiles with regard to demographic characteristics by using a Chi-square test

\begin{tabular}{|c|c|c|c|c|}
\hline Demographic variable & $\mathrm{X}^{2}$ & df & $\begin{array}{c}\text { Critical value } \\
(0.0 \text { l level) }\end{array}$ & Conclusion \\
\hline Household size & 2.62 & 4 & 13.28 & No significant difterence \\
\hline Age of respondent & 3.81 & 4 & 13.28 & No significant difterence \\
\hline Household income & 6.59 & 5 & 15.09 & No significant difference \\
\hline Cars in household & 6.25 & 4 & 13.28 & No significant difference \\
\hline Time spent on occupation/profession & 0.45 & 3 & 11.36 & No significant difference \\
\hline Education level & 2.32 & 4 & 13.28 & No significant difference \\
\hline Proximity of shops & 0.93 & 1 & 6.64 & No significant diffèrence \\
\hline Physical disability & 0.34 & 1 & 6.64 & No significant diftèrence \\
\hline Children & 1.99 & 1 & 6.64 & No signiticant ditference \\
\hline Pre-school children & 1.26 & 2 & 9.21 & No signiticant ditterence \\
\hline Time spent on cummunity/welfare activities & 3.04 & 4 & 13.28 & No signiticant ditference \\
\hline Working of shifts & 2.64 & 1 & 6.64 & No significant difference \\
\hline Time spent on fitness/sport & 0.32 & 4 & 13.28 & No significant difference \\
\hline
\end{tabular}


Table 2 Rotated factor loadings for 8-factor solution

\begin{tabular}{|c|c|c|c|c|c|c|c|c|}
\hline Item & $\begin{array}{c}\text { Factor I } \\
\text { Time (Save) }\end{array}$ & $\begin{array}{c}\text { Factor } 2 \\
\text { Fun }\end{array}$ & $\begin{array}{c}\text { Factor } 3 \\
\text { Credit }\end{array}$ & $\begin{array}{c}\text { Factor } 4 \\
\text { Select }\end{array}$ & $\begin{array}{c}\text { Factor } 5 \\
\text { Cost (Save) } \\
\end{array}$ & $\begin{array}{l}\text { Factor } 6 \\
\text { Unique }\end{array}$ & $\begin{array}{l}\text { Factor } 7 \\
\text { lnform }\end{array}$ & $\begin{array}{c}\text { Factor } 8 \\
\text { Enbar }\end{array}$ \\
\hline TIMEI & 0.769 & 0.098 & 0.059 & 0.014 & 0.017 & -0.076 & -0.007 & -0.068 \\
\hline TIME2 & 0.693 & 0.022 & -0.006 & -0.003 & -0.089 & 0.158 & 0.071 & 0.075 \\
\hline TIME3 & 0.674 & -0.048 & -0.026 & 0.048 & 0.074 & 0.010 & -0.019 & 0.132 \\
\hline TIME4 & 0.583 & 0.015 & -0.014 & 0.024 & 0.108 & -0.006 & 0.038 & 0.004 \\
\hline FUNI & 0.118 & 0.918 & 0.020 & -0.021 & -0.064 & 0.012 & -0.010 & -0.070 \\
\hline FUN2 & -0.035 & 0.914 & 0.026 & 0.051 & 0.032 & -0.017 & -0.020 & 0.052 \\
\hline FUN3 & -0.124 & 0.409 & 0.017 & 0.026 & 0.120 & 0.195 & 0.169 & 0.232 \\
\hline CREDITI & -0.016 & 0.074 & 0.738 & -0.092 & 0.087 & -0.033 & 0.171 & 0.062 \\
\hline CREDIT2 & 0.023 & 0.033 & 0.707 & 0.137 & 0.010 & 0.069 & $-(0.116$ & 0.044 \\
\hline CREDIT3 & 0.030 & 0.009 & 0.662 & 0.095 & 0.028 & -0.022 & 0.198 & 0.015 \\
\hline SELECT1 & -0.006 & 0.043 & -0.063 & 0.870 & 0.003 & -0.009 & 0.067 & 0.083 \\
\hline SELECT2 & 0.068 & -0.014 & 0.173 & 0.607 & -0.003 & 0.064 & 0.031 & -0.074 \\
\hline $\cos T 1$ & 0.083 & -0.022 & 0.070 & 0.016 & 0.799 & 0.064 & 0.018 & 0.004 \\
\hline $\cos T 2$ & 0.120 & 0.049 & 0.066 & 0.031 & 0.557 & 0.182 & 0.051 & 0.047 \\
\hline UNIQUEI & 0.042 & 0.043 & 0.050 & 0.035 & 0.049 & 0.688 & 0.140 & 0.014 \\
\hline UNIQUE2 & -0.040 & 0.043 & 0.093 & 0.133 & 0.150 & 0.508 & 0.033 & 0.088 \\
\hline UNIQUE3 & 0.116 & 0.087 & -0.069 & 0.081 & 0.191 & 0.436 & 0.030 & -0.050 \\
\hline INFORMI & -0.010 & 0.075 & 0.015 & 0.073 & 0.047 & 0.011 & 0.698 & 0.089 \\
\hline INFORM2 & 0.105 & -0.067 & 0.114 & 0.098 & -0.014 & 0.090 & 0.640 & -0.063 \\
\hline EMBARI & 0.060 & 0.055 & 0.008 & 0.087 & 0.125 & -0.079 & 0.043 & 0.640 \\
\hline EMBAR2 & 0.130 & -0.000 & 0.186 & -0.003 & -0.144 & 0.155 & 0.018 & 0.535 \\
\hline EIGENVALUES & 1.971 & 1.895 & 1.595 & 1.219 & 1.102 & 1.077 & 1.047 & 0.828 \\
\hline
\end{tabular}

2. Fun - the excitement related to the opening of a package received as well as the placing of an order by mail order (three items).

3. Credit - the simplicity and straightforwardness of credit arrangements and payments (three items).

4. Select - the wide selection of products offered by mail-order catalogue (two items).

5. Cost saving - because of no travel costs and no middlemen that share in profits (two items).

6. Unique - the products offered are exclusive to mail order because they are not available in retail shops (three items).

7. Inform - sufficient information to make informed buying decisions as well as clear procedures for the ordering of products (two items).

8. Embarrassment - purchasing of privacy items and the fact that a consumer's ignorance is not exposed (two items).

\section{Reliability}

The remaining 21 items were then, as suggested by Churchill (1995), subjected to an internal reliability analysis using the computer programme SAS PROC CORR (SAS Institute, 1988). Cronbach alpha values reported in Table 3 show that all the underlying dimensions of the construct 'reasons for purchasing low involvement low priced goods by mail order' are measured by an instrument with sufficient reliability $(\propto>$ 0.7 ) and that the Cronbach alpha of the entire instrument is 0.94 . This figure exceeds the minimum of 0.7 suggested by Peterson (1994) and Nunnally (1978) and confirms the reliability of the instrument.

\section{Confirmatory factor analysis}

The proposed instrument to measure reasons for purchasing low involvement goods by mail order (Table 4) was then subjected to a confirmatory factor analysis. The results, set out in Table 5, suggest that the 8-factor model in Figure 1 represents a reasonable fit to the data (Hair, Anderson, Tatham \& Black, 1998: 656). Table 5 also contains a comparison of the 8-factor model with the 11 -factor model The better fit of the 8-factor model is evident from the values of the measures of fit. The confirmatory factor analysis also provides some evidence of the construct validity of the proposed instrument (Tull \& Hawkins, 1993: 318).

When comparing the 8-factor solution with the 11-factor solution in Table 4 , it is clear that the 8 -factor solution offers

Table 3 Reliability results

\begin{tabular}{lc}
\hline Dimension & $x$ \\
\hline Time saving & 0.82 \\
Fun & 0.86 \\
Credit & 0.87 \\
Select & 0.81 \\
Cost saving & 0.85 \\
Unique & 0.81 \\
Inform & 0.80 \\
Embarrassment & 0.70 \\
Overall & 0.94 \\
\hline
\end{tabular}


Table 4 Items to measure reasons for purchasing low involvement low priced goods by mail order

\begin{tabular}{ll}
\hline Time saving & No travelling to shops \\
TIMEI & No queues in shops \\
TIME2 & No search for parking \\
TIME3 & Avoidance of travel costs \\
TIME4 & \\
Fun & Mail catalogue shopping is fun \\
FUN1 & Ordering is fun \\
FUN2 & Excitement of receiving a parcel \\
FUN3 & \\
Credit arrangements & Easy understandable credit arrangements \\
CREDIT1 & Simple paperwork \\
CREDIT2 & Straightforward arrangements \\
CREDIT3 & \\
Wide selection & Wide selection \\
SELECT1 & Attractiveness of choice \\
SELECT2 & \\
Cost saving & Privacy \\
COSTI & Po middlemen \\
COST2 & Less acquisition costs \\
Unique products & \\
UNIQUE1 & Non availability at retail shops \\
UNIQUE2 & Importance of exclusiveness \\
UNIQUE3 & Uniqueness is an incentive \\
Product information & \\
INFORM1 & \\
INFORM2 & Parchasing of personal items \\
EMBAR1 & EMB embarrassment \\
\hline &
\end{tabular}

Table 5 Comparison of 8- and 11-factor models

\begin{tabular}{lcc}
\hline Measures of fit & 8 Factor & 1/ Factor \\
\hline RMSEA & 0.068 & 0.073 \\
Modified AIC & 1.473 & 3.967 \\
LISREL GFI & 0.904 & 0.824 \\
LISRED adjusted GFI & 0.863 & 0.775 \\
Tucker-Lewis Index & 0.921 & 0.867 \\
RMR & 0.061 & 0.066 \\
\hline
\end{tabular}

a superior fit in all instances. The modified AIC for instance improves from 3.967 to 1.473 and GFI from 0.824 to 0.904 , whilst the RMSEA declines from 0.073 to 0.068 .

\section{Conclusion}

In conclusion it can be stated that the instrument developed, has demonstrated sufficient reliability (Cronbach alpha values), discriminant validity (exploratory factor analysis) and construct validity (confirmatory factor analysis).

\section{Managerial implications}

This study has shown that the reasons why low involvement goods are purchased frequently by mail-order catalogue, are not exactly the same as the reasons suggested in the literature. Eight reasons for low involvement products are supported by this study.

The findings of this study should, however, be interpreted with the respondents studied in mind. The reasons why people shop by means of mail-order catalogue that are cited in the literature but apparently not applicable to low involvement goods, according to this study, are guarantees, flexible shopping hours and personalised nature of offerings. To the respondents, who have become accustomed to purchasing goods by mail-order catalogue, those reasons do not appear to be important. This is not too difficult to comprehend, given the type of goods, namely low priced and low involvement goods, involved.

The study adds a new dimension to our understanding of nonstore patronage behaviour other than the traditional demographic predictors that are usually utilised. The findings of the study could be of value to mail-order catalogue managers. Due to the limited space in and the high cost of mail-order catalogues, it is important to concentrate only on those specific reasons that appeal to high frequency purchasers of low involvement low priced goods. This study identified the eight important ones. Given that consumers buy by mail-order catalogue for eight reasons, the results reported here could be used as a type of customer satisfaction survey. For instance, to what extend does a firm succeed in satisfying the customer's needs in terms of:

- Time saving

- Fun

- Credit arrangements

- Width of merchandise offered

- Cost saving

- Uniqueness of merchandise offered

- Information needed for decision making

- Prevention of embarrassment.

Apart from using the eight reasons as dimensions for measurement of customer satisfaction, these reasons can also be used as bases for target marketing strategies aimed at retaining loyal customers. Catalogues targeting customers who purchase by catalogue for specific reasons are more likely to retain their customers. The increasing opportunity costs of time and the desire for convenience and recreation by today's consumers, warrant a focus on the following issues by mailorder organisations:

- The processes of ordering, payment and delivery should be as convenient as possible. Customers could, for instance, be given the option to select between ordinary and express delivery at an increased price for the latter.

- Variety and prevention of embarrassment are important to mail-order customers. Special attention will thus have to be given to the information that is needed for decision making to reduce any uncertainty that might emanate from the non-availability of a product for personal inspection. The opportunity to evaluate the items in a catalogue, is a salient attribute of the catalogue shopping experience.

- The importance of recreation as a reason for buying by mail order is confirmed by this study. This aspect, which 


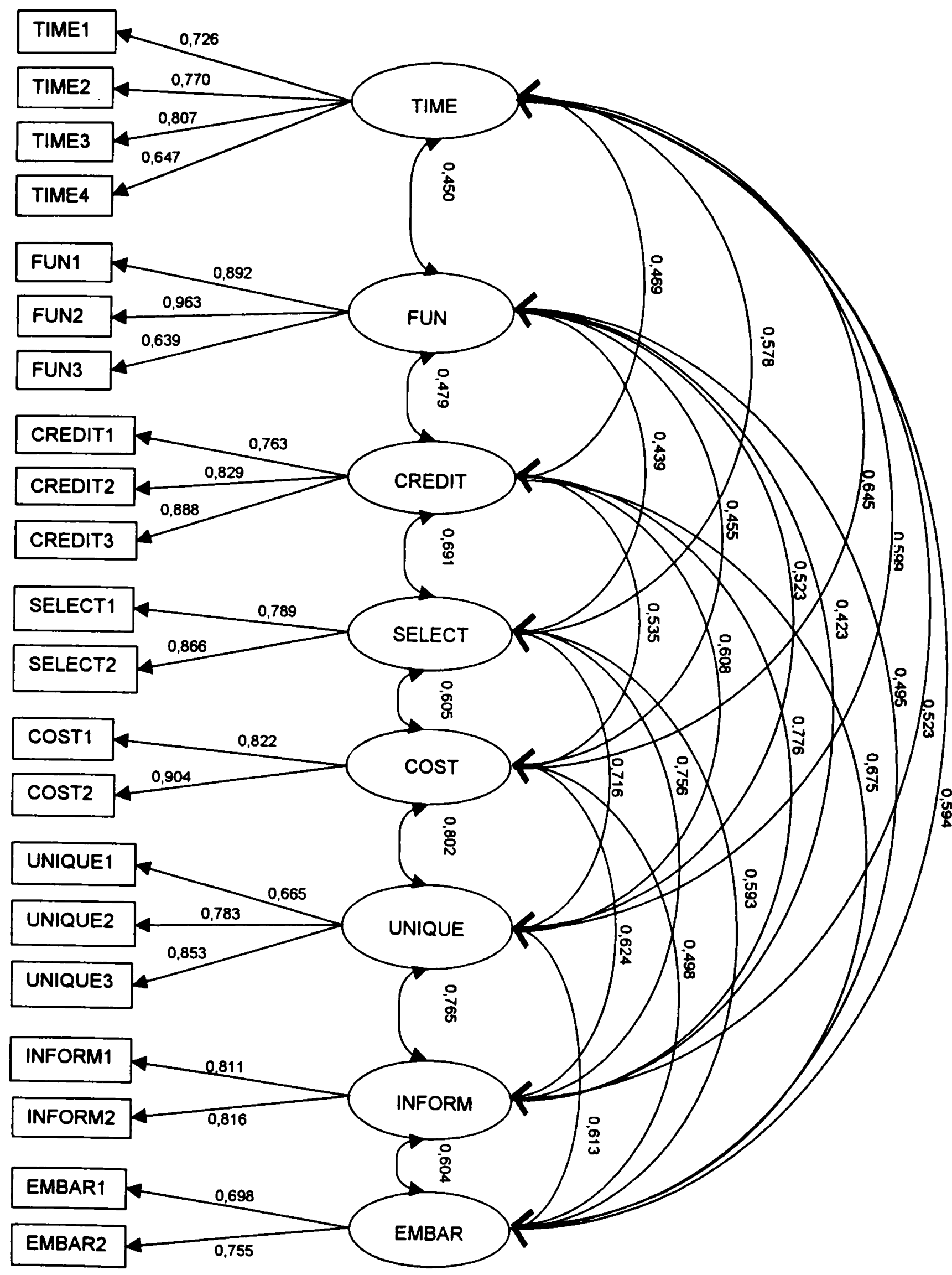

1) All $p$ values $<0,01$

Figure 1 Eight-factor model 
has grown in importance in the design of shopping facilities, presents a particular challenge to mail-order catalogue marketers.

\section{Acknowledgement}

The help of Mr Chris Pentz in the collection and capturing of the data is herby acknowledged.

\section{References}

Akaah, I.P. \& Korgaonkar, P.K. 1988. A conjoint investigation of the relative importance of risk relievers in direct marketing, Journal of Advertising Research, 28(4): 38-44.

Armstrong, J.C. \& Overton, T.S. 1977. Estimating nonresponse bias in mail surveys, Journal of Marketing Research, 14: 396-402.

Berkowitz, E.N., Walton, J.R. \& Walker, O.C. (Jr.). 1979. In-home shoppers: the market for innovative distribution systems, Journal of Retailing, 55(2): 15-33.

Berry, L.L. 1979. The time buying consumer, Journal of Retailing, 55(4): 58-69.

Churchill, G.A. (Jr.). 1995. Marketing research: methodological foundations. 6th Ed. Fort Worth: Dryden Press, 1117p.

Cox, D.F. \& Rich, S.U. 1967. Perceived risk and consumer decision making. In Risk taking and information handling in consumer behaviour. Cox, D.F. Ed. Boston: Harvard University Press, 487$506 \mathrm{p}$.

Cunningham, I.C.M. \& Cunningham, W.H. 1973. The urban inhome shopper: Socioeconomic and attitudinal characteristics, Journal of Retailing, 49(3): 42-50,88.

Darian, J.C. 1987. In-home shopping: are there consumer segments?, Journal of Retailing, 63(2): 163-186.

Gehrt, K.C. \& Carter, K. 1992. An exploratory assessment of catalog shopping orientations, Journal of Direct Marketing, 6(1): 29-39.

Gillett, P.L. 1976. In-home shoppers - an overview, Journal of Marketing, 40(4): 81-88.

Hair, J.F. (Jr.), Anderson, R.E., Tatham, R.L. \& Black, W.C. 1998. Multivariate data analysis. 5th Ed. Upper Saddle River: Prentice Hall, 730p.
Hawes, J.M. \& Lumpkin, J.R. 1986. Perceived risk and the selection of a retail patronage mode. Journal of the Academy of Marketing Science, 14(4): 37-42.

Hodgson, R.S. 1980. The Dartnell direct mail and mail order handbook. 3rd Ed. Chicago: The Dartnell Corporation

Jennich, R.I. \& Sampson. P.F. 1966. Rotation for simple loadings. Psychometrika, 31: 313-323.

Korgaonkar, P.K. 1984. Consumer shopping orientations, non-store retailers, and consumers' patronage intentions: a multivariate investigation, Journal of the Academy of Marketing Science, 12(1) $11-22$.

Lumpkin, J.R. \& Hawes, J.M. 1985. Retailing without stores: an examination of catalog shoppers. Journal of Business Research. 13(2): 139-151

McDonald, W.J. 1993a. Consumer preference structure analysis. Journal of Direct Marketing, 7(1): 20-30.

McDonald, W.J. 1993b. The roles of demographics, purchase histories, and shopper decision-making styles in predicting consumer catalog loyalty, Journal of Direct Marketing, 7(3): 55-65.

McNair, M.P. \& May. E.G. 1978. The next revolution of the retailing wheel, Harvard Business Review. 56(5): 81-91.

Nunnally, J. 1978. Psychometric theory. 2nd Ed. New York: McGraw-Hill.

Peterson, R.A. 1994. A meta-analysis of Cronbach's coefficient alpha, Journal of Consumer Research, 21(3): 381-391.

Rapp, S. \& Collins, T. 1990. The great marketing turnaround. Englewood Cliffs : Prentice-Hall, 336p

Reynolds, F.D. 1974. An analysis of catalog buying behavior, Journal of Marketing, 38(3): 47-51.

Rosenberg, L.J. \& Hirschman, E.C. 1980. Retailing without stores. Harvard Business Review. 58(4): 103-112.

SAS Institute Inc. 1988. SAS Procedures (Release 6.03 Edition) Cary, N.C.: Author.

Tull, D.S. \& Hawkins, D.I. 1993. Marketing research: measurement \& method. 6th Ed. New York: Macmillan Publishing, 863p. 